\title{
Where did you cry? Crafting Categories, Narratives, and Affect through Exhibit Design
}

\author{
CORINNE A. KRATZ \\ Emory University and Museum of International Folk Art
}

This special issue of Kronos fruitfully focuses on fraught issues related to persons who are missing and missed. Examining the processes involved in becoming 'missing, and how the categories related to being missing and missed are created, can offer ways to consider how historical knowledge and political meanings are produced and contested, as well as how diverse disciplinary formations and perspectives come together to constitute such knowledge and meanings. The papers attest to the instability, indeterminacy, and power relations that can pervade questions about evidence - numbers, events, memories, images, and a range of categories (what is a funeral? who is a 'civilian'? who is counted among the dead?) - as narratives and knowledge about the missing are constituted across a range of contexts.

Museum exhibits are one such context, providing a powerful resource through which cultural categories are created and popular histories are shaped and narrated. ${ }^{1}$ In the process, exhibits can spark the affective and evaluative freight of categories, histories, and narratives, provoke questions, and evoke memories and experiences. Exhibition design is essential to these processes and effects, drawing together verbal, visual, audial, material, and spatial media to craft categories, stories, values, and emotional engagement, as well as to mediate visitors' understandings and experiences. ${ }^{2}$ In thinking about the practices and issues that swirl around 'missingness', exhibition design offers a productive way to examine how the categories, histories, and politics related to missing persons and the 'unsettled dead' ${ }^{3}$ are incorporated into, and produced through, exhibits.

Colleagues at the African Critical Inquiry Programme's 2018 Workshop 'Missing and Missed: The Subject, Politics and Memorialisation of South Africa's Colonial and Apartheid Dead' offered comments and discussion that helped sharpen this paper, as did the Kronos reviewers. Thanks are also due to Nicky Rousseau, Riedwaan Moosage and Ciraj Rassool for organising the workshop and this special issue.

1 An extensive literature in critical museology addresses issues concerning the poetics and politics of representation. Among authors who consider history exhibitions in particular are A. Coombes, History After Apartheid (Durham NC: Duke University Press, 2003); R. Handler and E. Gable, The New History in an Old Museum (Durham NC: Duke University Press, 1997); I. Karp and S. Lavine (eds), Exhibiting Cultures (Washington DC: Smithsonian Institution Press, 1991); I. Karp, C. Kratz, L. Szwaja, T. Ybarra-Frausto, et al. (eds), Museum Frictions: Public Cultures/Global Transformations (Durham, NC: Duke University Press, 2006); B. Lord, 'From the Document to the Monument' in S. Knell, S. MacLeod and S. Watson (eds), Museum Revolutions (London: Routledge, 2007), 355-366; N. Murray and L. Witz, Hostels, Homes, Museum (Cape Town: University of Cape Town Press, 2014); C. Rassool and S. Prosalendis (eds), Recalling Community in Cape Town (Cape Town: District Six Museum Foundation, 2001); L. Witz, G. Minkley and C. Rassool, Unsettled History (Ann Arbor: University of Michigan, 2017).

2 C. Kratz, The Ones That Are Wanted: Communication and the Politics of Representation in a Photographic Exhibition (Berkeley: University of California Press, 2002); C. Kratz, 'Rhetorics of Value: Constituting Worth and Meaning through Cultural Display', Visual Anthropology Review, 27, 1, 2011, 21-48.

3 Forensic History Group, 'Workshop Call: Missing and Missed, The Subject, Politics and Memorialisation of South Africa's Colonial and Apartheid Dead', October 2017, 2. 
To do this, I draw on my recent work on the History Galleries ${ }^{4}$ in the Smithsonian's National Museum of African American History and Culture (NMAAHC) in Washington DC, and supplement this with other examples. The captures and removals central to slavery and lynching in the US bring particular comparative angles to other forms and histories of missingness discussed elsewhere in this special issue.

As a mainstream museum on the Mall's national stage, the NMAAHC addresses a wide audience. Opened to great acclaim in September 2016, the museum seeks to recast popular understandings of national history, to show that 'African American history is American history', and to 'propel a national conversation around race, around history. ${ }^{5}$ This meant the History Galleries had to navigate segregated memories, histories, and scholarship, and to recalibrate relations among different strands and representations of popular history. ${ }^{6}$ Further, the Galleries had to address a political and cultural moment, when striking connections among popular understandings of history, US ethno-racial formations, and the innumerable ways that we still live in a world made by slavery' were increasingly prominent and recognised. ${ }^{7}$ Design was essential in shaping the broad narrative framework through which the exhibit seeks to recast popular history, providing ways to define actors, actions, events, connections, and relationships.

The NMAAHC has eight levels and 8,000 square metres of exhibition space (see Figure 1). ${ }^{8}$ The History Galleries, encompass the three lower levels of the building, which are located underground (see below for more on other levels). Here, woven into the Galleries' sweeping four-hundred-year canvas, are episodes and modes of missingness that have helped constitute US society through slavery, colonialism, the

4 C. Kratz, 'Redesigning Popular Histories Through Exhibits' paper presented at the Peabody Museum, Harvard University, 24 April 2017. My research on the NMAAHC exhibits began in November 2016, soon after the museum opened, and forms part of a larger project on exhibition design as a persuasive and interpretive interface for visitors, crafted from multiple media (C. Kratz, 'Rhetorics of Value: Exhibition, Design, Communication', unpublished manuscript). While other works examine how exhibits are produced - S. Macdonald, Behind the Scenes at the Science Museum (Oxford: Berg, 2002); E. Linenthal, Preserving Memory: The Struggle to Create America's Holocaust Museum (New York: Columbia University Press, 2001); Kratz, The Ones; M. Bunzl, In Search of a Lost Avant-Garde (Chicago: University of Chicago Press, 2014); H. Morphy, 'Sites of Persuasion: Yingapungapu at the National Museum of Australia' in Karp, et al., Museum Frictions, 469-499; J. Shannon, Our Lives: Collaboration, Native Voice, and the Making of the National Museum of the American Indian (Santa Fe, NM: SAR Press, 2014); and others - my focus here is on design form as communication, rather than on the history of exhibit design or the design process per se. My research has involved half-a-dozen visits to NMAAHC galleries in 2016 and 2017 (25 to 30 hours of gallery time), closely documenting design elements, layout, and content, and also observing and interacting with visitors; informal interviews with visitors in other contexts; and comparative visits to other commemorative museums. Additional visitor comments were collected when I presented my preliminary analysis at several venues; this analysis has also been circulated to NMAAHC staff. In addition, I have collected many reviews of the NMAAHC exhibits, which often describe visitors' reactions as well as those of the reviewers.

5 Museum director Lonnie Bunch, quoted in K. Capps, 'Don't Call it the Blacksonian', Citylab, 30 December, 2016. http://www. citylab.com/design/2016/12/don't-call-it-the-blacksonian-lonnie-bunch-on-americas-best-new-museum/511934/ (accessed 8 March 2017).

6 F. Ruffins, 'Revisiting the Old Plantation' in Karp et. al., Museum Frictions, 394-434 and Kratz, 'Redesigning', provide more on different strands of popular and scholarly history in the US and their historiographical shifts, noting important trends towards social history that reframed perspectives and topics in the 1970s and 1980s. The museum created a Scholarly Advisory Committee to assist in creating exhibitions, https://nmaahc.si.edu/about/leadership (accessed 6 September 2018). In addition, Lonnie Bunch, many NMAAHC curators, and some researchers at Ralph Appelbaum Associates (the lead designers for NMAAHC) hold PhDs in fields related to social and cultural history. Prominent historians (including Eric Foner, Leslie Harris, Jennifer Morgan, Annette Gordon-Reed, and others) were consulted as the History Galleries were developed. 'The Future of the African American Past', a conference organised in 2016 by NMAAHC and the American Historical Association to mark the opening of the museum, also offered insight into historiographical approaches used in developing the displays; see https:// futureafampast.si.edu/program (accessed 6 September 2018).

$7 \quad$ K. Schulz, 'Derailed', The New Yorker, 22 August 2016, 71.

8 With thanks to the NMAAHC and the Smithsonian Institution for allowing for fair use of the content in Figure 1. https://www. si.edu/termsofuse, accessed 31 January 2019. 


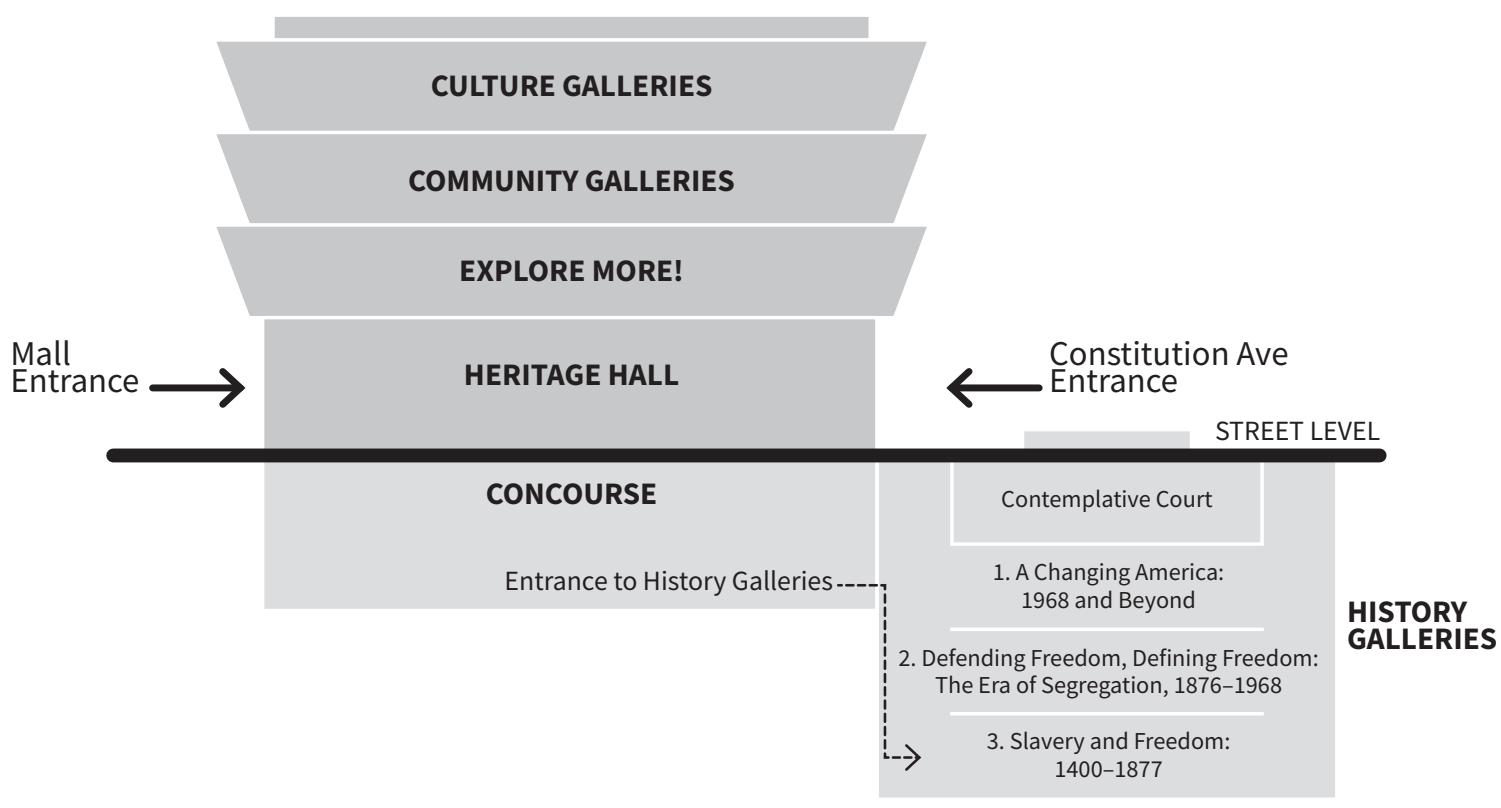

Figure 1: Schematic Plan of the National Museum of African American History and Culture.

Source: Adapted from https://nmaahc.si.edu/visit/maps

post-Revolutionary and Civil War eras, the years of Reconstruction and Jim Crow laws, the civil rights era, and contemporary times. Comparative historians might bring these into conversation with other situations where missingness has helped to define political processes and personal experiences, whether other slave-trade locations, South Africa's colonial and apartheid dead, those disappeared in Northern Ireland, Argentina, or Chile, genocides in Europe, Africa, and Asia, or similar cases. ${ }^{9}$ However, considering how missingness is designed and presented in the History Galleries can also raise questions about categories and relations that constitute states of being missing and being missed, and how these are construed as memory and history. This further foregrounds narrative tensions around personhood, and around the processes and dynamics of humanising/dehumanising that are often fundamental to situations where particular groups of people are systematically disappeared, removed, and made missing. Finally, the Galleries also provide a way to think about how affect and engagement are produced via design - how does missing become missed for visitors? Brito, C. Gonzalez Enriquez, and P. Aguilar (eds), The Politics of Memory: Transitional Justice in Democratizing Societies (Oxford: Oxford University Press, 2001); G. Gatti, Surviving Forced Disappearance in Argentina and Uruguay (New York: Palgrave Macmillan, 2014); P. Hayner, Unspeakable Truths (New York: Routledge, 2001); R. Shaw, 'Memory Frictions', International Journal of Transitional Justice 1, 2, 2007, 183-207. Forced disappearances have occurred in some three dozen countries. See Wikipedia, 'Forced disappearance'. https://en.wikipedia.org/w/index.php?title=Forced_disappearance\&oldid=818907831 (accessed 10 January 2018). 
These three sets of issues - categories, narratives, and engagement - are interlaced in exhibit design. The categories and how they relate to one another are foundations for the exhibit's narratives and humanising/dehumanising dynamics, while the narratives simultaneously shape changing notions of those categories and of how they interrelate. All combine in the ways that visitors interpret and become caught up in the Galleries. I recognised particularly intense modes of visitor engagement at NMAAHC after speaking with a number of first-time visitors, and I realised that I could - and should - include a question unusual for museum-visitor interviews: 'Where did you cry'? As NMAAHC director Lonnie Bunch commented, 'I have seen visitors moved to tears in our History Galleries. Their emotional response is not a surprise ... [We are] wrestling with difficult issues and creating moments for people to really consider the pain of slavery, segregation, and racial violence. ${ }^{10}$ But tears can be enigmatic - denoting pain, sadness, anger, relief, empathy, joy. They are 'visible evidence that a person has been deeply moved', but the nature of that emotion may vary. ${ }^{11}$ Further, tearful moments in the History Galleries are part of broader and variable emotional contours in the exhibit and the museum more generally. Tracing these salient responses provides ways to consider how exhibit design might shape such experiences and interpretations, and how they have such effects.

\section{Categories and conditions}

Neither Bunch nor the History Galleries characterise these difficult histories in terms of forced or involuntary disappearance. That category, expressed in several related phrases, gained attention in international bodies in the 1970s within the framework of human-rights law (although it should be noted that human-rights campaigns share deeper roots with the anti-slavery movements of the nineteenth-century). ${ }^{12}$ The entry text where visitors take the elevator down to the History Galleries does signal this connection:

African Americans have had an uneven history in this country. They came initially as forced labor to support the nation's economic development. But they brought with them a spirit that had a powerful impact. Their struggles for human rights forced the nation to rethink the meaning of freedom and equality ... over more than 400 years. (emphases added)

African American history is marked by 'forced labor', 'forced migration', and 'forced service' - sharing the elements of coercion and human rights violation with forced disappearance, but differing significantly in terms of political and economic

10 L. Bunch, Letter to Charter Members, National Museum of African American History and Culture (November 2017); see also P. McGlone, 'African American Museum Designed with Emotions in Mind', The Washington Post, 17 April, 2016, https://www. washingtonpost.com/lifestyle/style/african-american-museum-designed-with-emotions-in-mind/2016/04/17/6cdbedaa-fldc11e5-a61f-e9c95c06edca story.html?utm term=.c2783f8850fe (accessed 6 September 2018).

11 J. Elkins, Pictures and Tears: A History of People Who Have Cried in Front of Paintings (New York: Routledge, 2004), 38.

12 T. Keenan, 'Getting the Dead to Tell Me What Happened' in Forensic Architecture (eds), Forensis: The Architecture of Public Truth (Berlin: Sternberg Press, 2014), 40-41. 
circumstances, broad social acceptance historically, and the enduring and transforming nature of oppression and coercion. ${ }^{13}$ The story told in the History Galleries is national, a history of the US, but initially it is framed globally, in relation to 'The Making of the Atlantic World' and to how the 'Emerging Global Economy' was taking shape in both Africa and Europe in the 1400s. ${ }^{14}$ The exhibit shows how the nation was born in tight embrace with the global slave trade, and how grappling with the violence, racism, and contradictions entailed in that embrace has shaped its structures, laws, identities, and ideologies up to the present. Rather than focus on the kinds of state-sponsored violence associated with campaigns of forced disappearance that have occurred in the last fifty years, the History Galleries show a pervasive system of discrimination that developed from international trade and capitalism and became entrenched, defined and condoned within the US political economic system since its inception through governmental structures and actions. People became not just 'objects of administration, ${ }^{15}$ but 'economic objects' and, during slavery, 'items of trade and labor.'

The Galleries show this in a variety of ways, beginning with the statement:

Five hundred years ago, a new form of slavery transformed Africa, Europe, and the Americas. For the first time, people saw other human beings as commodities - things to be bought, sold, and exploited to make enormous profits. This system changed the world.

Opening sections use objects, images, audio, and text to show how this system worked and how it shaped the emerging colonial society, defining different kinds of people through legal and economic relations, as well as through other social boundaries: ${ }^{16}$

Enslaved Africans, European indentured servants, and Native Americans worked alongside one another as they cultivated tobacco. They also intermarried, socialized, ran away, and rebelled together. Fearful of interracial alliances and eager for profits, planters saw slavery as a safer and cheaper option. Africans were ultimately defined as 'enslaved for life', and the concept of whiteness began to develop. ${ }^{17}$

13 Disappearance does not figure prominently in the exhibit, although friends and families surely experienced slave-trade abductions, the sale of family members, and lynching in similar ways. The section on the 1955 murder of Emmett Till does make this link, marking the time in which he was missing as the middle phase on a case timeline which reads: 'Decision to go to Mississippi'; 'Disappearance of Emmett Till'; and 'Discovery and Publicity'.

14 Capitalised phrases are drawn from section titles and panel headings in the exhibit.

15 J. Edkins, Missing: Persons and Politics (Ithaca: Cornell University Press, 2011), 7.

16 H. Riesch, 'Theorizing Boundary Work as Representation and Identity', Journal for the Theory of Social Behaviour, 40, 4 (2010), 452-473; C. Briggs, 'Beyond 'Banned Words': The CDC, Trump's Anti-science, and Anthropological Outrage', Somatosphere: Science, Medicine, and Anthropology, 2018, http://somatosphere.net/2018/01/beyond-banned-words.html (accessed 6 January 2018).

17 Exhibit developers draw here on work in critical whiteness studies, a field often traced back to W. E. B. DuBois, and burgeoning since the 1990s. B. Appelbaum, 'Critical Whiteness Studies' in George Noblit (ed.), Oxford Research Encyclopedia of Education, June 2016 (accessed 7 September 2018). 


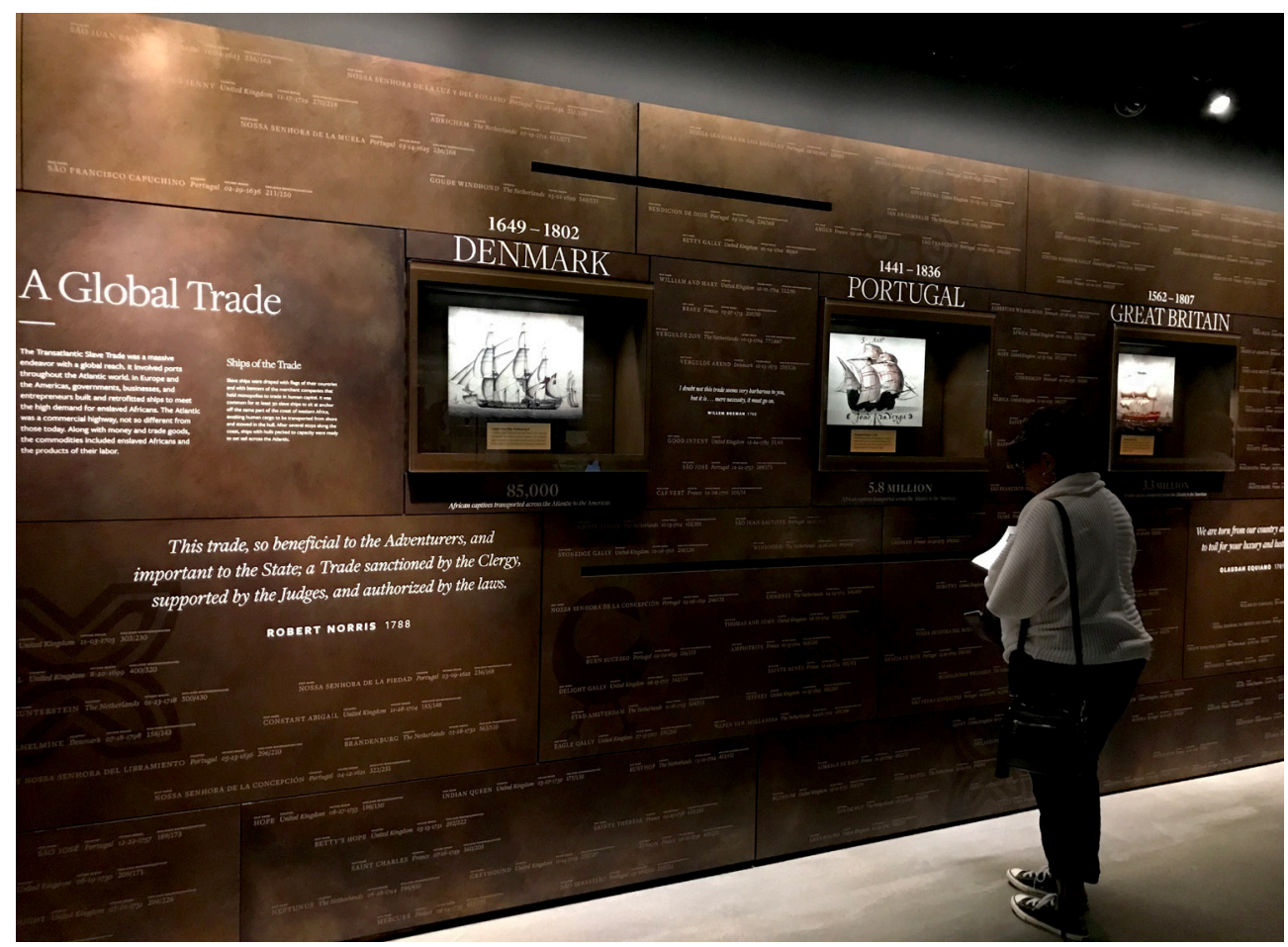

Figure 2: The 'Ships of the Trade' wall demonstrates the global nature of the slave trade and identifies major slave-trading nations, their years of involvement, and total slaves transported. Quotes stenciled on the wall in white foreground different perspectives and positions on the slave trade at the time. Photograph by Corinne A. Kratz.

A wall devoted to 'Ships of the Trade' underlines the international nature and scale of the system. Wall vitrines show the ships used by five major slave-trading countries, their years in the trade, and total captives transported, ranging from 85,000 for Denmark to 5.8 million for Portugal (Figure 2). A simple background pattern, stencilled in gold onto the copper-coloured wall, provides a devastating display of the quotidian transformation of people into objects (Figure 3), listing the names of slave ships with their country of origin, voyage date, and the heartbreaking ratio of the number of enslaved boarded versus those who survived the voyage. ${ }^{18}$ Two quotes stencilled in white script offer contradictory perspectives from the time - a technique that is used throughout the galleries. Together this pair emphasise the systemic, accepted, objectifying nature of the slave trade, as well as its human and social cost:

18 The, 'Axé Bahia' exhibit at the Fowler Museum at the University of California in Los Angeles in 2017, used an effective time-lapse video to map the more than twenty thousand voyages made by over fifteen thousand ships that serviced the trans-Atlantic slave trade's from 1545 to 1860 . In contrast to NMAAHC's focus, it shows that relatively fewer ships sailed to North America and that far more, over a longer period, went to Brazil and the Caribbean. See a version of the video at Slate, http://www.slate.com/ articles/life/the_history_of_american_slavery/2015/06/animated_interactive_of_the_history_of_the_atlantic_slave_trade.html (accessed 18 January 2018). 
SHIP MAME COUNTRY VOYAGE BEGAN ENSLAVED BOARDED/SURVIVED

GUSTAVE ADOLPHE France 07-13-1787 29/14

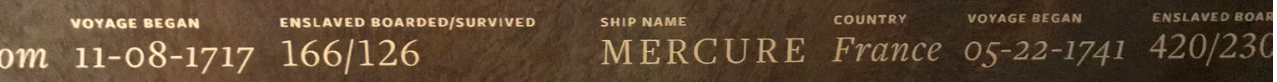

VOYAGE BEGAN ENSLAVED BOARDED/SURVIVED SHIPNAME COUNTRY VOYAGEBEGAN ENSLAVEOBOARD

lands $10-22-1722 \quad 778 / 746$

SCIPION France $12-16-1713$ 110/71

SMIP MAME COUNTRY VOYAGE DEGAN ENSLAVED BOARDED/SURVIVEO

AIGLE AGUILA NEGRA France 07-16-1702 500/107

COLAAS The Netherlands $03-02-1756 \quad 270 / 91$

Figure 3: The repeating background pattern in the 'Ships of the Trade' section, shown in gold type, lists the names of slave ships, their country of origin, voyage date, and the ratio of enslaved who boarded to those who survived the journey. One of several instances of 'massing techniques' used in the History Galleries, this also illustrates the dehumanisation of treating humans as cargo. Photograph by Corinne A. Kratz.

This trade, so beneficial to the Adventurers, and important to the State; a Trade sanctioned by the Clergy, supported by the Judges, and authorized by the Laws.

- Robert Norris 1788

We are torn from our country and friends, to toil for your luxury and lust of gain.

- Olaudah Equiano 1789

In these and other ways, the design of the opening sections begins to outline the fundamental dynamics of personhood that provide a thematic framework for the Galleries; namely, the tension between humanising and dehumanising (see below). Slavery illustrates its first incarnation and historical grounding in the exhibit, and offers an initial parallel and contrast for later situations - each with their own dynamics of personhood - where people are systematically made missing. The thematic framework weaves through the exhibit, but the History Galleries highlight two other important patterns of practice with parallels to modes of missingness: the decades of African American lynching that proliferated after the Civil War and continued through and beyond the Jim Crow era, and the systematic and disproportionate 


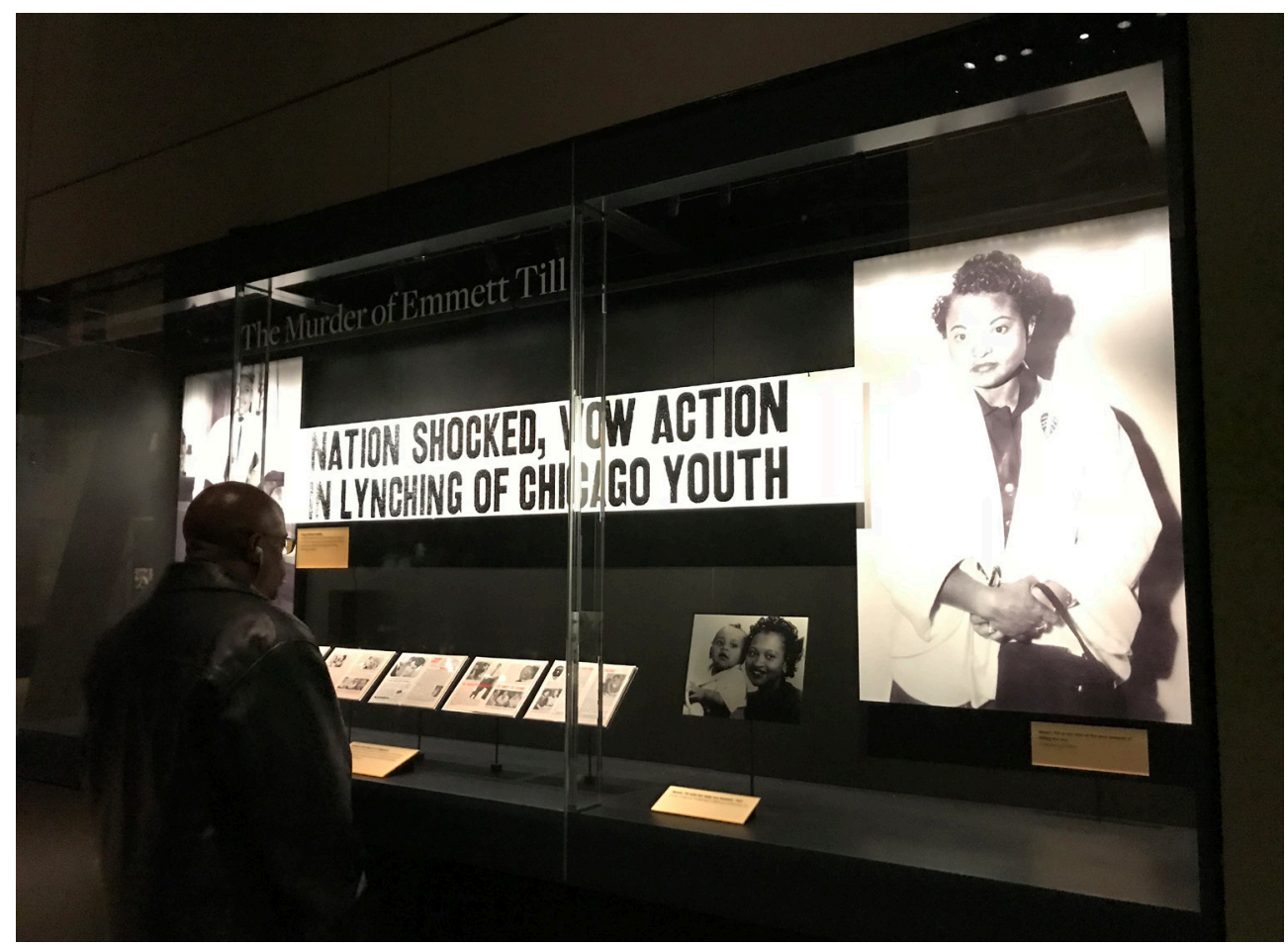

Figure 4: The 1955 murder of Emmett Till features in a gallery where his casket is displayed as if in a funeral home. Determined that the world would see the results of the savage treatment her son received, Mamie Till-Mobley held an open-casket viewing which was attended by tens of thousands and mobilised political action. This display case is outside the gallery; no photographs may be taken inside. Photograph by Corinne A. Kratz.

incarceration of young black men, characterised by Michelle Alexander as the New Jim Crow. ${ }^{19}$ The roots of the latter in slavery and the 'Convict Labor System' are outlined through the display of a guard tower from Angola Prison, and revisited in the Community Galleries' Power of Place exhibit, but they do not receive the same attention as slavery and lynching.

Like political disappearances, slavery and lynching both involved abductions of some sort. ${ }^{20}$ For families, the people who disappeared into slavery were removed to a version of the 'indeterminate state of being' that the Forensic History Group describes for missingness -'neither present in their life nor absent through a 'forensic' confirmation of their death. ${ }^{21}$ Slaves were subject to further separations and indeterminacies when families were split and sold, a wrenching mode of missingness marked in the exhibit through objects and audio in the 'Domestic Slave Trade' section, particularly parts called 'The Weeping Time' and 'Sold Away' (see below). 
Audio of dramatic readings from WPA Slave Narratives marks the pain of missing loved ones:22

I had a brother Jim who was sold to dress the young missus for her weddin'. And I set dar an' I cry an' cry, specially when they puts the chains on him an' carries 'im off. An' I ain't never felt so lonesome in my whole life. - Ben Johnson 1937

Lynching is presented in a range of ways: institutionally, as a widespread method of terrorism intended to sustain white supremacy in the era that gave rise to the $\mathrm{Ku}$ Klux Klan as well as to anti-lynching movements; historically, as it increased in relation to particular civil-rights gains and when the insecurity around lynching helped motivate northern migration; and personally, through particular cases and newspaper articles. Extended treatment of the murder of Emmett Till, who was savagely beaten and slain in Mississippi in 1955, highlights both his mother's pain and distress at the abduction, torture, death, and missingness of her son and how her pain took political form to galvanise thousands to view his body, demonstrate, and march (Figure 4).

While the NMAAHC does not deal with situations now most commonly associated with politically motivated campaigns of forced disappearance, the ways in which the History Galleries present the conditions, practices, relations, and categories associated with slavery and lynching offer revealing comparisons, parallels, and counterpoints to situations where people are missing and missed. In particular, they show how underlying discrimination and dehumanising are normalised and how a particular ethno-racial system of categories, laws, and institutions was formed in the US. These processes can be related and contrasted to other ethno-racial and political circumstances and histories. Certain parallel design treatments occur in the sections on slavery and lynching, revealing these to be part of the grounding dynamics of US history while also connecting them to other situations in which people are missing and missed.

\section{Design dynamics: narrative tensions of personhood and scale}

Two linked thematic tensions thread through the History Galleries' narrative framework. One (noted above) centres on personhood, exploring the opposition between humanising and dehumanising treatments of African Americans over four hundred years. The other concerns actions and events through which humanising and dehumanising occurred - alternating moments of resistance/rebellion and violence against African Americans. These are woven into section after section by, for example,

22 The Slave Narratives collection was produced through the Federal Writers' Project, part of the Works Project Administration (WPA) agency, which was created in the US during the New Deal to employ people during recovery from the Great Depression. Transcription here largely follows the way Johnson's speech is presented in the records of the WPA's Federal Writers Project; see Federal Writers Project, Slave Narratives (Washington DC: Library of Congress, 1941), http://lcweb2.loc.gov/mss/mesn/112/112. pdf (accessed 12 May 2018). 
including a key revolt, rebellion, or protest as part of each colonial regional profile as well as similar examples on a timeline of legislation that traces 'The Expansion of Slavery' or the 'Call for Freedom.'23

The denial of the humanity and personhood of African Americans underpinned and enabled slavery, lynching, and racism generally. The same denial has often been extended to others in campaigns of disappearance elsewhere. As noted, the Galleries open with a statement on how slavery turns people into objects; the dehumanising involved in this commodification recurs in the 'Domestic Slavery' section and elsewhere. The design technique of juxtaposing contradictory quotes also foregrounds this dehumanising/humanising tension, with contrasting references to people as payload versus people who have friends in the example cited earlier, and the contrast of commodity versus men in the following pair:

Negroes ... are a perishable Commodity, when you have an opportunity ... Dispose of them for gold.

- Humphrey Morice 1730

O, ye nominal Christians! Might not an African ask you - Learned you this from your God, who says unto you, Do unto all men as you would men should do unto you?

- Olaudah Equiano 1789

Keenan draws attention to the instability of claims to humanity, 'not secured by anything, subject to regular challenge and contest. ${ }^{24}$ Related to this are variable notions of personhood across settings and the diverse practices through which it is claimed, produced, and contested. ${ }^{25}$ The History Galleries regularly address the changing legal frameworks through which jural personhood was constrained for African Americans, from early laws governing slavery, to the 'Black Codes after the Civil War,' 'Reconstruction', and battles in courts and legislatures over Jim Crow Laws, segregation, and voting rights. These parts of the exhibit are often text-heavy, but punctuated by poignant objects and images illustrating these constraints' pervasive effect on daily life, personal comportment, and other realms of personhood. For instance, introductory paragraphs about Jim Crow Laws are followed by an entire wall showing examples of the discriminatory laws listed by state; small white type set

23 Kratz, 'Redesigning, 18-19. I pay less attention in this article to how the second theme is designed into the galleries, but see 'Redesigning' for further analysis.

24 Keenan, 'Getting the Dead', 42-43.

25 The locus classicus for notions of personhood is M. Fortes, 'The Concept of the Person' in G. Dieterlen (ed.), La Notion de Personne en Afrique Noire (Paris: Editions de CNRS, 1973), 283-319; M. Fortes, 'Problems of Identity and Person' in A. JacobsonWidding (ed.), Identity: Personal and Sociocultural (Uppsala: Humanities Press, 1983), 389-401. See Fortes' work as summarised by I. Karp, 'Concepts of Personhood' in J. Middleton (ed.), Encyclopedia of Africa (New York: McMillan, 1997), 342-346. For a comparative analysis of how personhood is understood and produced in neonatal intensive care units in the US and Taiwan, see Y. Ren, 'Vi(Abilities): Biology, Personhood, and Agency in the Neonatal Intensive Care Unit in the US and Taiwan' (PhD dissertation, Emory University, 2011). For a range of African examples, see M. Jackson and I. Karp (eds), Personhood and Agency (Washington: Smithsonian Institution Press, 1990) and C. Kratz, 'Forging Unions and Negotiating Ambivalence: Personhood and Complex Agency in Okiek Marriage Arrangement' in D. Masolo and I. Karp (eds), African Philosophy and Cultural Inquiry (Bloomington: Indiana University Press, 2000), 136-171. 


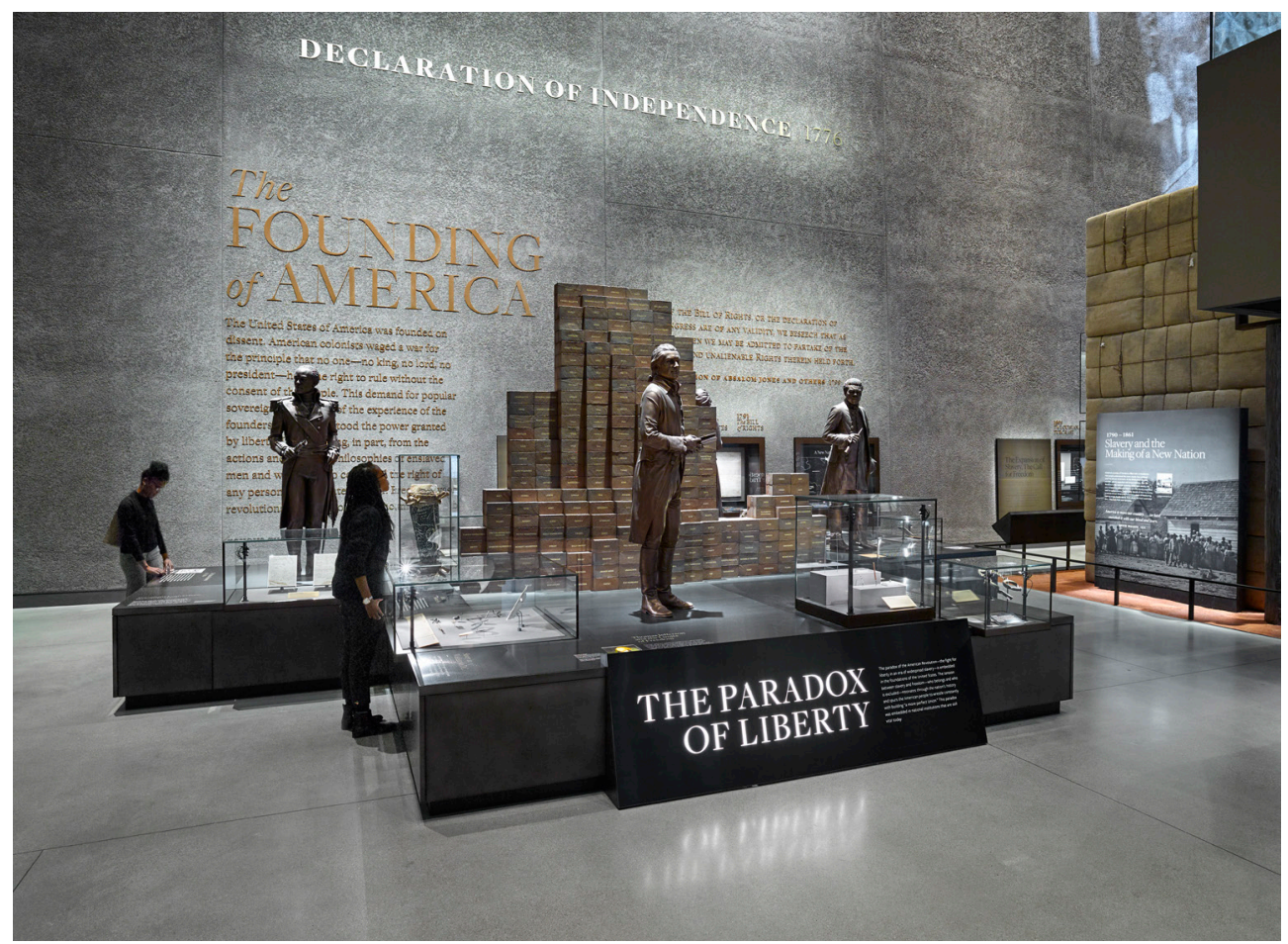

Figure 5: The high-ceilinged 'Paradox of Liberty' section in the History Galleries features a 360-degree display that highlights the activities of five individuals using statues and display cases (two are not visible in the image). Photograph by Alan Karchmer/NMAAHC.

against black and deep red backgrounds covers the wall. A small vitrine embedded in this wall of text contains a water fountain, a daily sign of segregated life. To the right of the wall is a large display case on 'The Rise of the Ku Klux Klan' which contains a prominent white hood; opposite this is a display on 'Ida B. Wells' Anti-Lynching Campaign' including a large portrait of Wells and several of her personal objects. ${ }^{26}$

These examples point to a telling design approach to the tensions of personhood that involves punctuating the exhibit with modes of personalisation. This includes incorporating profiles of particular individuals and events and using personal names in various ways. Such personalising can humanise abstract historical processes and complex events, introducing a sense of actors within a lived experience. Examples include a brief profile, book, and numerous quotes by Oloudah Equiano; a display case on Revolutionary soldier, Prince Simbo; statues with displays on five figures in the 'Paradox of Liberty' section (Figure 5); cases on Ida B. Wells, Nat Turner, Harriet

26 Another object whose poignancy is often cited in reviews is a tiny pair of shackles: 'heartbreakingly small ... with openings that are just 2.5 inches in diameter ... their five-pound bulk disturbingly heavy for the tiny wrists they confined. Despite their small size, they deliver a gut punch by summoning the horror and humanity of the slave trade'; McGlone, 'African American Museum'. The striking and poignant sense of such objects may arise from their very nature - the relationships they evoke, the personal stories they recall, their ability to encapsulate the difficulties and conundrums of living as a slave or under segregation - or from connections made by particular visitors, or, most likely, a combination of these factors. 


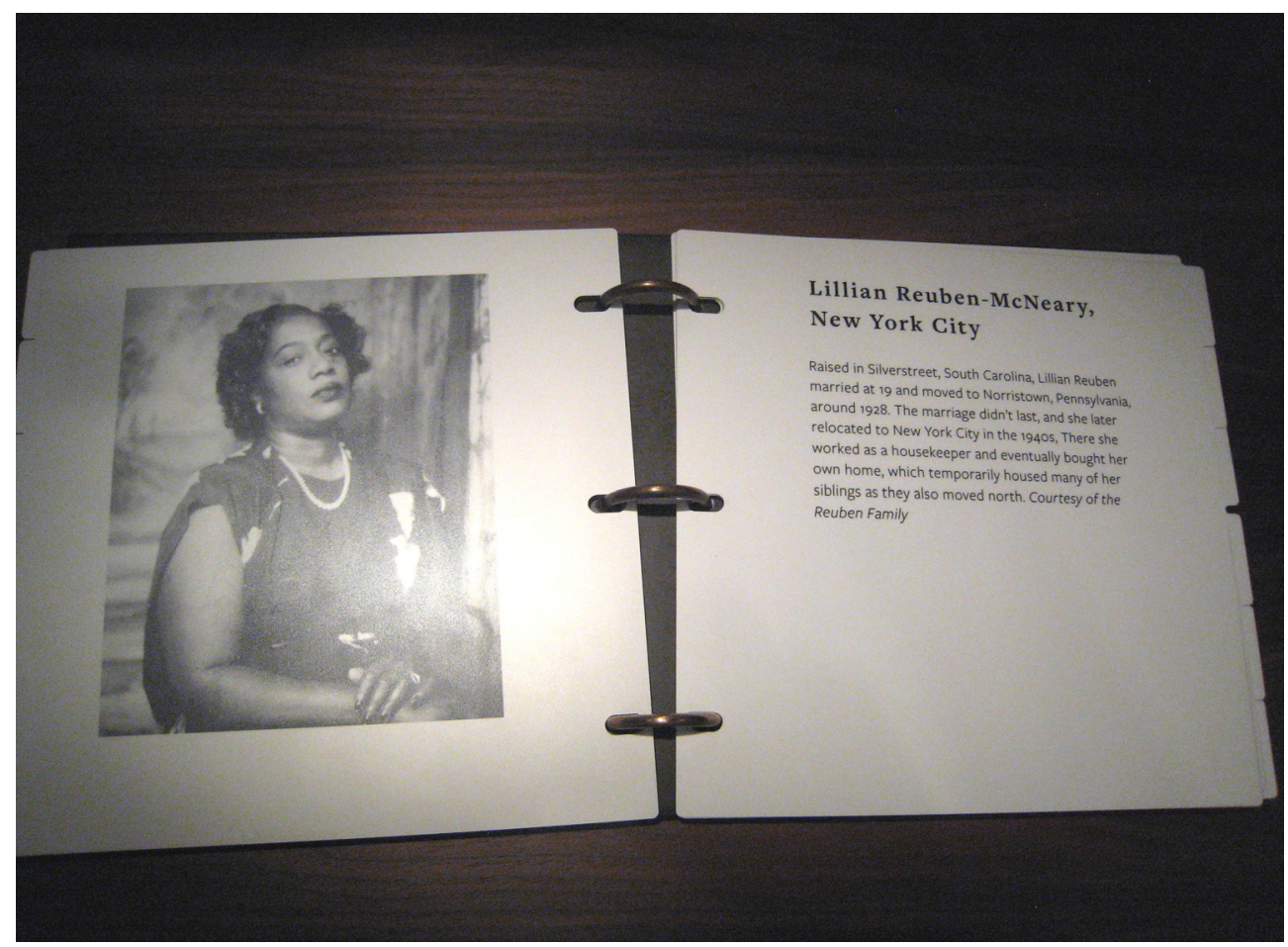

Figure 6: 'Migration Stories' in binders arranged on a table give visitors an opportunity to delve into the many ways in which particular individuals and families were part of the Great Migration, during which some 'six million African Americans moved from the South to northern, midwestern, and western states'. Photograph by Corinne A. Kratz.

Tubman, and 'The Story of Private Gordon'; ${ }^{27}$ notebooks with individual 'Migration Stories' (Figure 6); numerous photographic portraits; depictions of particular places; powerful personal narrative audio; evocative objects tied to personal stories; letters; and far more.

The use of personal names is also central to a set of design techniques that I refer to as 'massing techniques.' Throughout the History Galleries, massing techniques work across scales to convey both the systemic nature of slavery and lynching and their individual effects. The first occurrence of a wallpaper-like massing of names comes in the slave-trade section described above, listing slave ships by name, country, date, and enslaved survival ratios. The very absence of personal names here, as slaves become cargo statistics, underlines the trade's dehumanising nature. Later, in 'The Domestic Slave Trade' section, the background text stencilled onto the wall consists of 'excerpts from bills of sale', identifying individuals and prices, and as the label text puts it, telling 'a story of heartache, profit and dehumanization' (see Figure 7):

27 The figures in the 'Paradox of Liberty' section are Thomas Jefferson, Benjamin Banneker, Phyllis Wheatley, Elizabeth Freeman, and Toussaint L'Ouverture. During the Civil War, Private Gordon appeared in an iconic image showing the scars from savage beating on his back. 


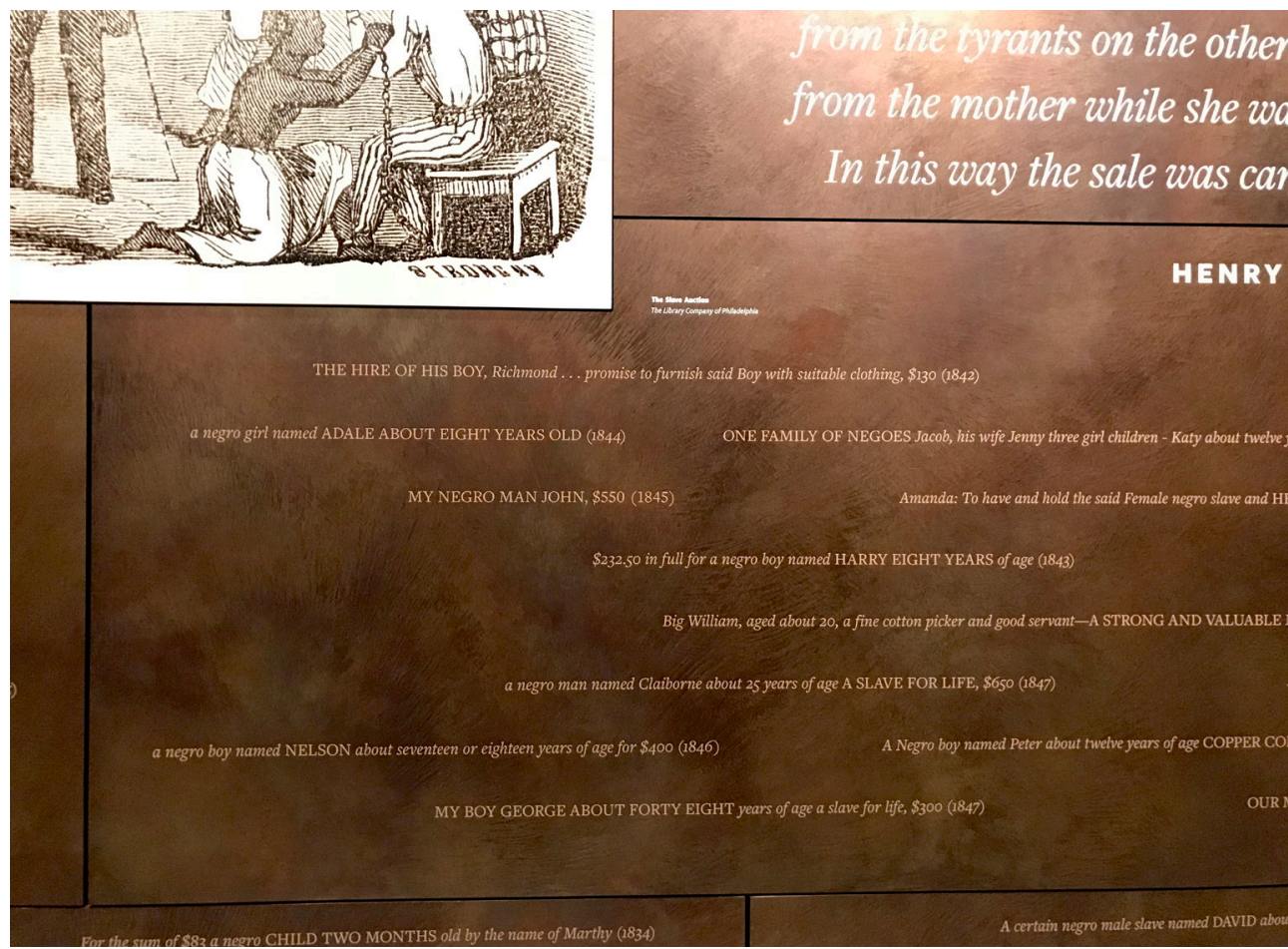

Figure 7: In 'The Domestic Slave Trade' section, the 'massing technique', used as a kind of 'wallpaper', shows excerpts from bills of sale for slaves. Photograph by Corinne A. Kratz.

a negro BOY NAMED GEORGE about fourteen or fifteen years of age or thereabouts, $\$ 600$ (1852)

A negro woman (LEAH) AND HER TWO CHILDREN Sarah and Mariah, $\$ 750(18 X X)$

I GIVE AND BEQUEATH TO MY SON ... my black woman, Delphy, a slave (1854)

Journalist Wesley Morris describes his reaction to the first of these: 'the decorative presentation has fooled then floored you. It's such a horrifyingly casual display that it becomes grimly amusing before it turns devastating. ${ }^{28}$

Another variation of the massing technique occurs with the statue of Thomas Jefferson in 'The Paradox of Liberty' section. Jefferson stands before a pile of bricks,

28 W. Morris, 'Visiting the African-American Museum: Waiting, Reading, Thinking, Connecting, Feeling', New York Times, 25 December, 2016, https:/www.nytimes.com/2016/12/25/arts/design/smithsonian-museum-african-american-museum-historyculture-wesley-morris.html (accessed 26 December 2016). 


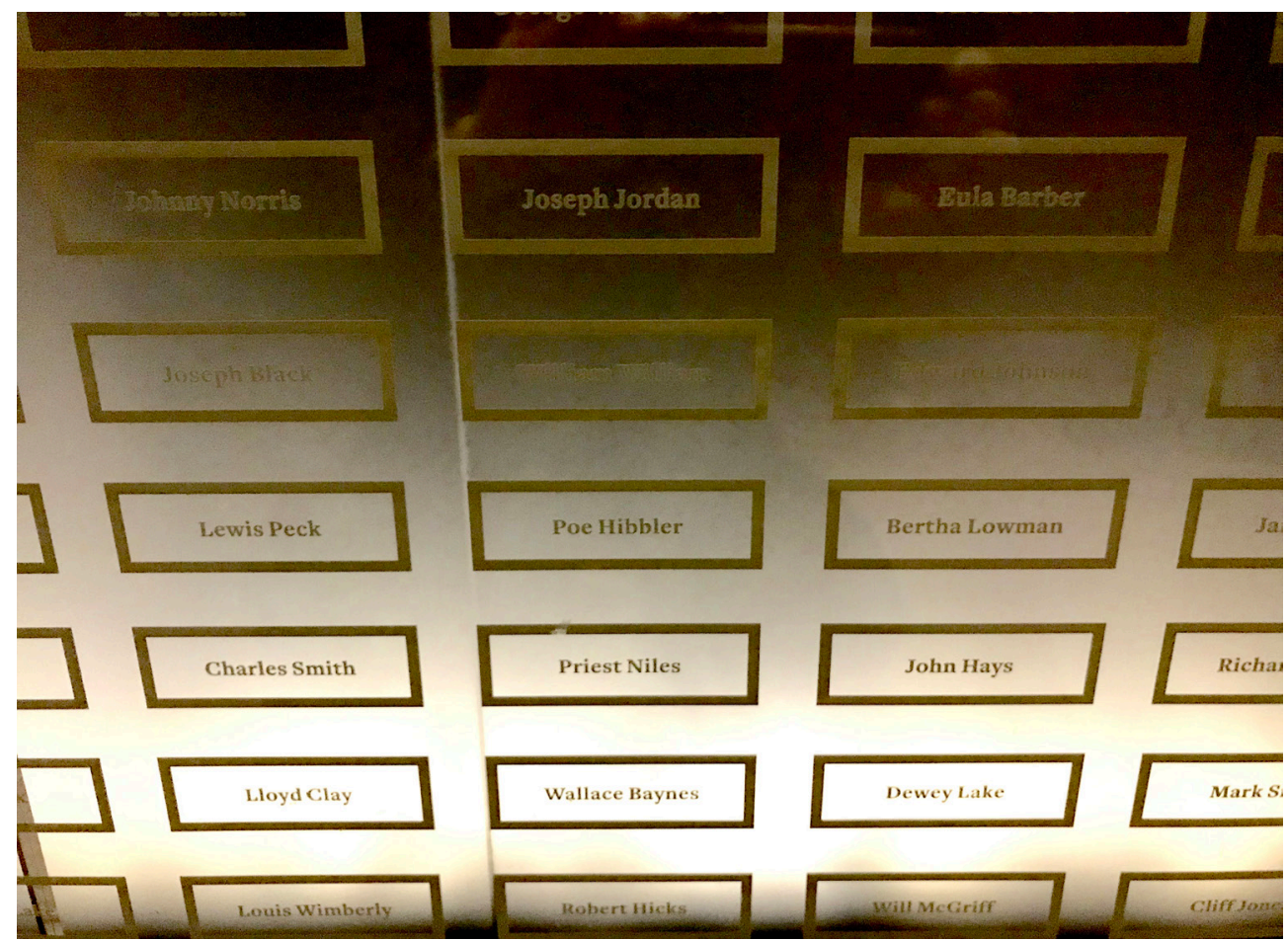

Figure 8: The names of people who were lynched are engraved along the bottom of glass cases in several parts of the History Galleries' second level, 'Defending Freedom, Defining Freedom: The Era of Segregation, 1877-1968'. Echoing the bricks behind the Jefferson statue, this repetitive pattern is the main 'massing technique' used on this level. Photograph by Corinne A. Kratz.

each inscribed with the name of one of his 609 known slaves. ${ }^{29}$ A label pointing to Jefferson's most famous slave reads: 'The people remembered here include six of Jefferson's enslaved children and their mother Sally Hemings.' Like the bills of sale, many of the bricks show only first names or no name at all, emphasising the dehumanising depersonalisation that denied slave identities, and contorted family ties as people were constantly separated through sales and other means. This technique carries into later displays, where small bricks appear again but with names now etched along the base of glass cases to represent lynching victims (Figure 8). These appear first in sections on 'Jim Crow Laws', 'The Rise of the Ku Klux Klan', and 'Ida B. Wells' Anti-Lynching Campaign'. They occur again at the base of glass panels on 'The Hardening of Racial Separation' and 'The Battle over Lynching'.

Using names in these ways creates a dynamic between individuals and multitudes, particular persons harmed and the vast scale of loss. The massing techniques honour those listed like a memorial would, yet simultaneously underline the horror. Making the names into wallpaper, a repeating background distinguished only

29 A photograph of the display is available at https://static01.nyt.com/newsgraphics/2016/08/26/museum-afam/assets/images/ view_jefferson5-1254.jpg (accessed 3 September 2018). The image itself could not be included here because of the New York Times' hefty usage fee. 
by the variation of particular names, reinforces not only the scale of devastation and its long history but the systemic nature of the slave trade, lynching, oppression, and discrimination. It emphasises that such actions have been embedded and justified within an ethno-racial formation and ideology that pervades past and present social and economic systems, stretches over centuries, and involves everyone. Recurring through the exhibit, these massing techniques further orchestrate the twin narrative tensions between dehumanising objecthood and humanising personhood and between violence and resistance. They provide a steady hum, a low chord sounding continually under the exhibit's historical narrative, albeit punctuated with important events, actions, and actors, portraits of specific people and experiences, and structured by stories of revolt and retaliation.

Versatile and poignant, modest and heartrending, massing techniques are also used in other display contexts related to the missing and loss, often connecting political economic and personal stories. One source of their potency is the long tradition of listing individual names on war memorials, dating back at least as far the 1860s. When Maya Lin designed the Vietnam Veterans Memorial as a Yale student in 1981, she responded to a design brief specifying that 'all the names of those missing or killed $(57,000)$ must be part of the memorial..$^{30}$ Aware of the power of names, her sitespecific design, with its descending $\mathrm{V}$-shaped wall of reflective black granite, 'worked ... on an emotional level ... [It was] experiential and cathartic.' ${ }^{31}$ Ten years later, Ralph Appelbaum Associates incorporated the emotional weight of listing names in their design for the US Holocaust Memorial Museum. Varied forms of the technique are used there, as they are in Appelbaum's later designs for NMAAHC. In the Holocaust Museum, names engraved on glass list individual victims, communities lost, and authors whose books were burned. Massing techniques with photographs and objects are also used. ${ }^{32}$

Different modes of massing names and images, then, are a multiply evocative design technique. They can also represent different phases and moments as the

30 Some trace the practice to 1870 and the Franco-Prussian War; see, for example, https://en.wikipedia.org/wiki/War memorial\#cite_note-2 (accessed 7 September 2018), but it was developing earlier than that. In the early 1800s, a memorial in Washington DC listed the names of officers who had served, and local Civil War monuments through the 1890s sometimes named those in a community who had died, although usually omitting African American soldiers - see G. K. Piehler, Remembering War the American Way (Washington DC: Smithsonian Institution Press, 1995), 23, 53. Individual war graves, and listing names on memorials, became more common with World War I, along with identity tags for soldiers. When there were no bodily remains, names were sometimes all that was left, and monuments could become 'little more than a venue for names' - T. Laqueur, 'Memory and Naming in the Great War' in J. Gillis (ed.), Commemorations (Princeton: Princeton University Press, 1994), 163-164; see also D. Sherman, 'Art, Commerce, and the Production of Memory in France after World War I' in J. Gillis (ed.), Commemorations (Princeton: Princeton University, 1994), 186-211. The design brief to which Maya Lin responded followed this practice of including lists of names.

31 M. Lin, 'Making the Memorial', New York Review of Books, 2 November 2000, https://www.nybooks.com/articles/2000/11/02/ making-the-memorial/ (accessed 16 September 2018).

32 An intersecting lineage for massing techniques in relation to the missing includes the marches, demonstrations, and displays in Peru, Chile, Argentina, and elsewhere that featured innumerable photographic posters showing and identifying the disappeared; see J. Edkins, 'Politics and Personhood: Reflections on the Portrait Photograph', Alternatives: Global, Local, Political 38, 2, 2013, 139-154). Subsequent memorials and museums carried on the convention, evoking the anguish of the times. Similarly, folk artists in Peru (such as retablo maker Claudio Jimenez Quispe) later depicted the horrors of the Internal Armed Conflict (1980-2000) as a kind of testimony. Both the photographic-massing convention and folk art became part of a recent exhibit on 'Crafting Memory: The Art of Community in Peru' at the Museum of International Folk Art. For examples of Latin American protests using masses of images, see https://www.csmonitor. com/World/Americas/2018/0112/In-wake-of-Fujimori-pardon-divided-Peru-debates-meaning-of-reconciliation; http://america.aljazeera.com/opinions/2014/1/argentina-conadeptruthcommissionhumanrights.html; and http://america. aljazeera.com/articles/2013/9/11/the-other-9-11-chilemarkscoupas40thanniversary.html (all accessed 30 May 2018). 


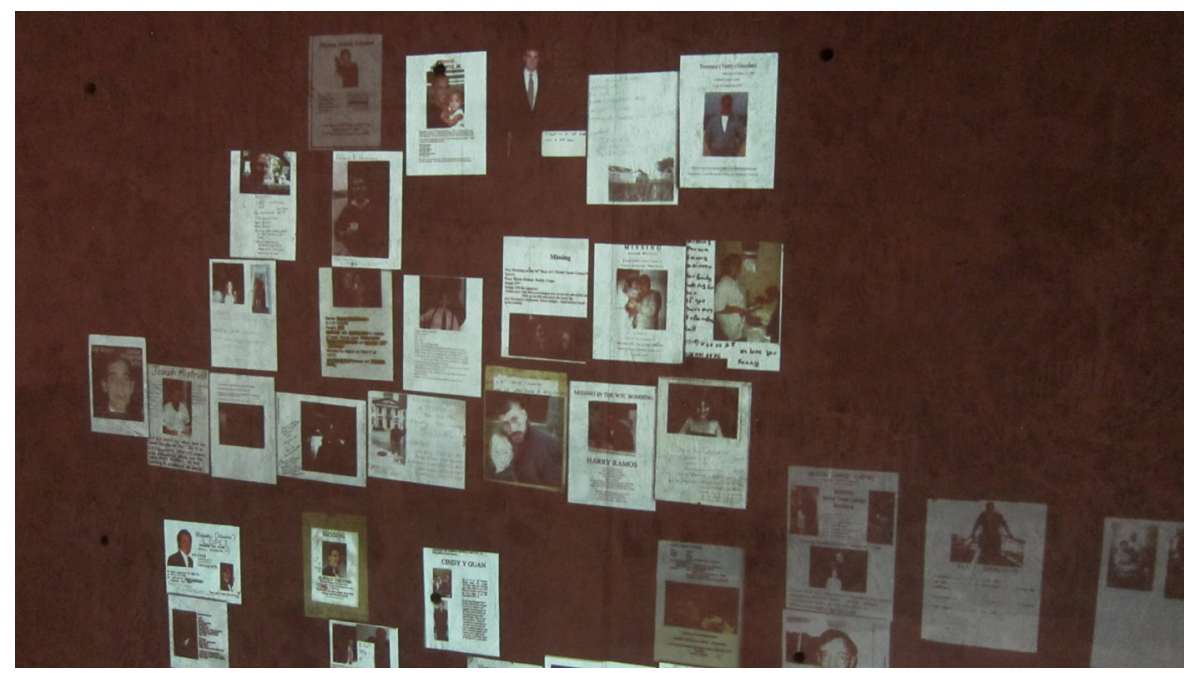

Figure 9

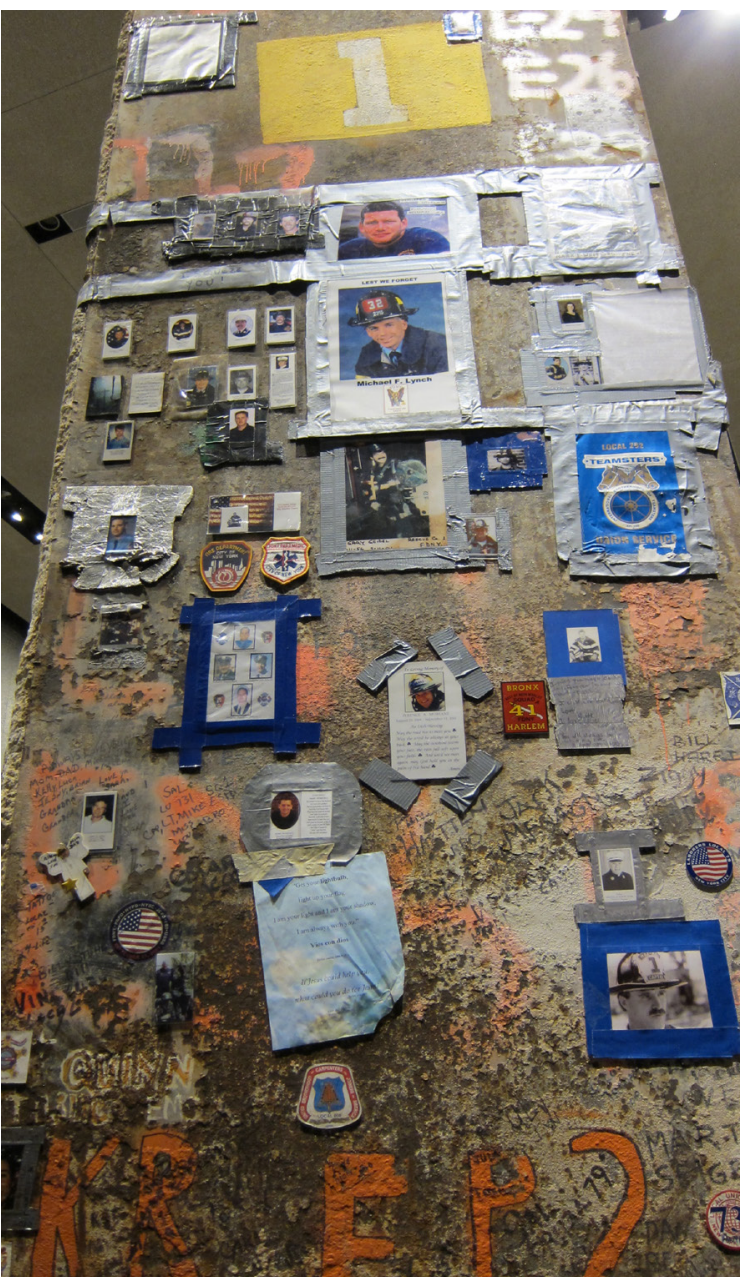

Figures 9-11: At the 9/11 Memorial and Museum in New York, the massing of names and images shows a progression through the exhibition, moving from posters that sought the missing soon after the 2001 attacks on the World Trade Center (Figure 9), to displays of remembrance posted on the Last Column to be removed from the site when the recovery effort ended in 2002 (Figure 10), to the names inscribed on the memorial itself (Figure 11). Photographs by Corinne A. Kratz.

Figure 10 


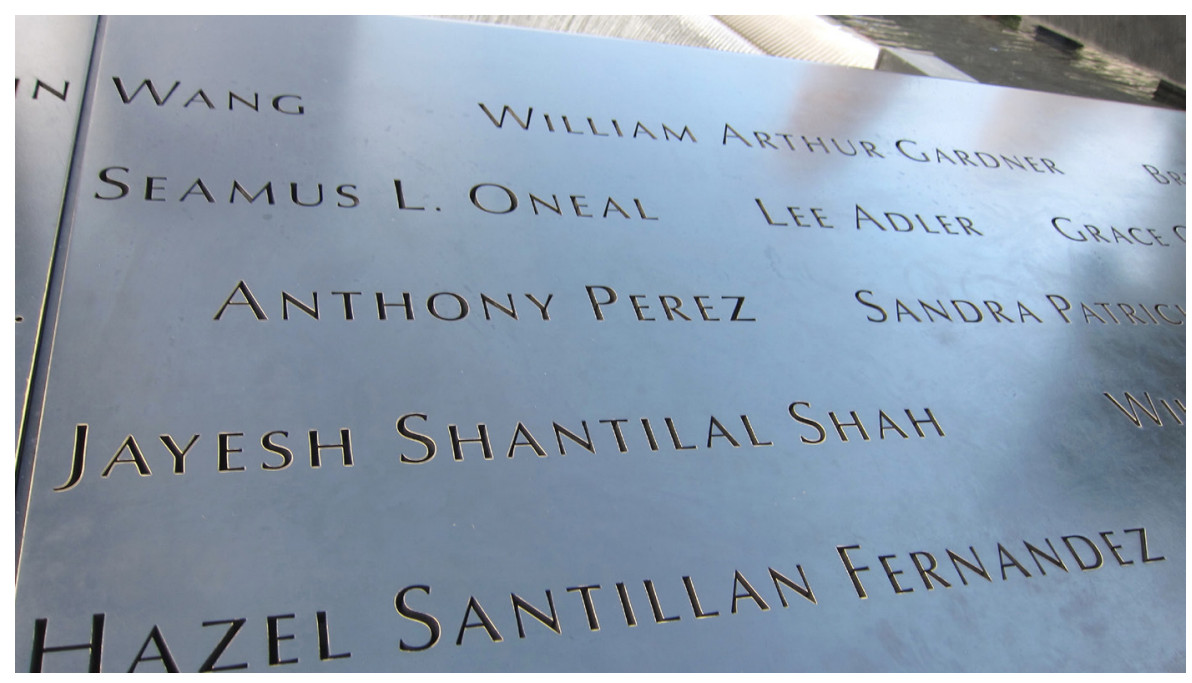

Figure 11

uncertainties and indeterminacies associated with the missing give way to the memorialised and deeply, permanently missed. This is explicit in the 9/11 Memorial and Museum in New York. Near the exhibition's entrance ramp, an array of the posters that sought the missing are projected on the walls. The depths of the museum contain a moving display of the Last Column, where the homemade and heartfelt missingperson posters have become personal memorials and remembrance notices. ${ }^{33}$ Finally, the Memorial, marking the World Trade Center's footprint with waterfalls and reflecting pools, is surrounded by a massing of nearly three thousand names of those lost, in more formal canonical inscriptions in the surrounding bronze parapets as the dead become 'units of new memorial complexes' (Figures 9-11). ${ }^{34}$

There is some movement across massing techniques in the NMAAHC exhibit, but no such clear trajectory. Covering four hundred years, rather than the compact timeline relevant to the $9 / 11$ Memorial and Museum, the thematic tension between humanising and dehumanising in the History Galleries creates more subtle dynamics that work across exhibition media. Thus, from the initial text that marks slavery's transformation of people into commodities and the first massing, where slaves are listed as cargo statistics, the bricks behind Jefferson name most of the enslaved by first name, but only a few have surnames. In the massing that marks later lynchings, most of the engraved bricks show first and last names, although some hold only a surname (White, Rivers, Jenkins, Myers, Pedigree) or a single name ambiguously first or last (Mayfield, Jordan, James, Davis). ${ }^{35}$ In other words, while these design techniques

33 The story of these notices on the Last Column can be found at https://www.911memorial.org/blog/story-behind-lastcolumn $\%$ E2\%80\%99s-first-markings (accessed 26 May 2018).

34 Forensic History Group, 'Missing and Missed', 4. On the names at the 9/11 Memorial, see https://www.911memorial.org/ locating-name-0 (accessed 18 January 2018).

35 The one-named lynching bricks likely reflect incomplete sources and records, but the prevalence of both first and last names marks the greater social and legal standing African Americans had gained by these times, even amidst the brutal practice. Similarly, one-name bricks marking the period of slavery reflect the assumption that people were property, and had no legal standing or need for their own surname apart from that of their 'owner.' 
depict pervasive and shifting institutionalisation of dehumanising practices, they also reveal gradual, if precarious, shifts in legal and social recognition of personhood.

These design approaches draw attention to connections across situations characterised by missingness and practices involved in creating large groups of missing people, such as slavery and lynching. As a way of combining scales, massing techniques simultaneously highlight systemic violations and pervasive personal implications for individuals, families, and communities. Examining categories of 'missing' across political settings might suggest certain common - perhaps universal - features of the conditions, processes, and political campaigns that produce mass disappearances. Dehumanisation is commonly used to erode and call personhood into question, for instance, but it is important to also address the particular socialhistorical circumstances and the specific and variable forms, meanings, and practices that constitute, question, and violate personhood in each case. ${ }^{36}$

Finding a balance in exhibit design that combines experiences and understandings that might be taken as near universal (such as certain kin connections or life events) with specific histories, meanings, and situations can be the basis of evocative exhibits that touch and affect, mediating interpretations as visitors also draw on their own experience and understandings. ${ }^{37}$ In this way 'the poetics of similarity and difference, of assimilating and exoticising' - an 'opposition [that] takes a variety of forms in different exhibition settings' - can combine and actuate critique through comparison and empathy. ${ }^{38}$ In NMAAHC's History Galleries, developing multi-layered ways to display and convey the narrative tensions between dehumanising/humanising and violence/resistance led to a carefully designed orchestration of stories and multi-sensory features that craft a powerful encounter for many visitors. Next, I consider such design effects and engagements, as well as how these might tie in with ways of thinking about and representing the missing and missed.

\section{Designing connection and critique}

The NMAAHC recasts popular understandings of US history in a variety of ways. But 'reorienting and recasting popular notions of history are not just about which facts and figures to include or incorporating other actors and events in an add-on approach. It is affective work as well. ${ }^{39}$ Elsewhere I consider how voice and emotional pacing are built into the History Galleries' design, ${ }^{40}$ but here I focus on how the humanising/dehumanising tension offers potential flash points as exhibit design creates

In some cultural settings, personhood is not limited to humans, but might recognise other beings - other animals, plants, spirits that interact with humans and act on the world through particular relationships and modalities of agency; see Jackson and Karp, Personhood and Agency; M. Hobart, 'The Patience of Plants: A Note on Agency in Bali', Review of Indonesian and Asian Affairs 24, 1990, 90-35; M. Allewaert, Ariel's Ecology: Plantations, Personhood, and Colonialism in the American Tropics (Minneapolis: University of Minnesota, 2013); J. Archambault, 'Taking Love Seriously in Human-Plant Relations in Mozambique', Cultural Anthropology 31, 2, 2016, 244-271.

37 Kratz, 'Rhetorics of Value', $28-29$.

38 I. Karp and C. Kratz, 'Reflections on the Fate of Tippoo's Tiger' in E. Hallam and B. Street (eds), Cultural Encounters: Communicating Otherness (London: Routledge, 2000), 198-199.

39 Kratz, 'Redesigning Popular Histories', 23.

40 Kratz, 'Redesigning Popular Histories', 23-25. 
affective contours, progressions, and crescendos. Slavery and lynching, the clearest bridges from the Galleries to thinking about and portraying the missing and missed, indeed provide potential moments of intense visitor connection, when design sets deeply dehumanising treatment against profound humanising practices. The two exhibit sections highlighted below both involve layered and sometimes dramatic design techniques, although severely reducing design elements can also enhance a particular focus and create emotional effect. ${ }^{41}$

'The Domestic Slave Trade' section evoked a strong response for me, heightening the narrative built up by previous sections. Stretching along a gallery wall, this area includes the wallpaper massing of documentation from slave sales, wrenching audio readings from WPA Slave Narratives, texts on the economy of human commodities, and 'The Weeping Time' sub-section, which focuses on the ways in which slaves were separated from their loved ones. Emotionally laden objects on display include an auction block, shown alongside images of slave sales, and 'Ashley's Sack' - a keepsake given to a young girl when she was sold, as a way to help her retain her connection with, and memory of, her mother and to fight this kind of 'missing' (Figure 12). ${ }^{42}$ The designed density of display techniques and pointed juxtapositions emphasise the tension of dehumanising treatment with humanising counteraction and associated subject/object tensions. ${ }^{43}$ The pervasive implications of the denial of personhood, how this was expressed in daily action and built into institutions is clearly shown. The cumulative effect builds a deeply felt sense of the system's inherent violence and of the toll this takes on individuals, families, and society.

The section on the death of Emmett Till held similar impact for me in relation to lynching (see Figure 4). In this instance, the designers isolated the area spatially in a corner gallery, and marked it as special with the sign that reads: 'No photography... as a request of the family.' The back part of the gallery holds Till's casket. The room is arranged as if for a funeral viewing, with a church-choir soundtrack and large photographs of Till himself, his mourning mother, as well as of the funeral. Quotes from Mami Till-Mobley and Rosa Parks throughout the area dramatise the mother's difficult, brave decision to allow her son's body to be shown publicly, in an open casket, and its galvanising political impact. After visitors file past the coffin, performatively joining the tens of thousands who viewed the body in 1955, they move into the front gallery where more background texts, images, and videos can be viewed. A quote by Rosa Parks placed nearby summarises the resolve and resistance Till's murder aroused: 'I thought about Emmett Till, and I could not go back.' By showing the

41 The side gallery on the Saõ José slave ship, which sank off the coast of South Africa in 1794, offers an example of this. It showcases a very limited number of objects recently salvaged from the wreck in a darkened space and spotlights a handful of powerful quotes. An audio treatment in the small gallery features dramatic readings of memoirs and letters, 'personal reflections of the Middle Passage experience from those who endured the journey or observed the slaves.' The final text panel is called 'Holding onto Humanity.'

42 Ashley was sold at the age of nine. The sack is embroidered with the tale. In exhibits, objects like Ashley's sack can seem to tell heartbreaking or uplifting stories, much as Keenan characterises the way 'bones speak' in the prosopopoeia of forensic investigation (Keenan, 'Getting the Dead'). Juxtapositions of objects or media can work similarly. See C. Kratz, 'Red Textures and the Work of Juxtaposition', Kronos 42, 2016, 29-47.

43 The audio reading of Lu Mayberry's affronted comment foregrounds both: 'They examine you just like they do a horse. They look at your teeth, and pull your eyelids back ... and feel you - just like you was a horse.' 


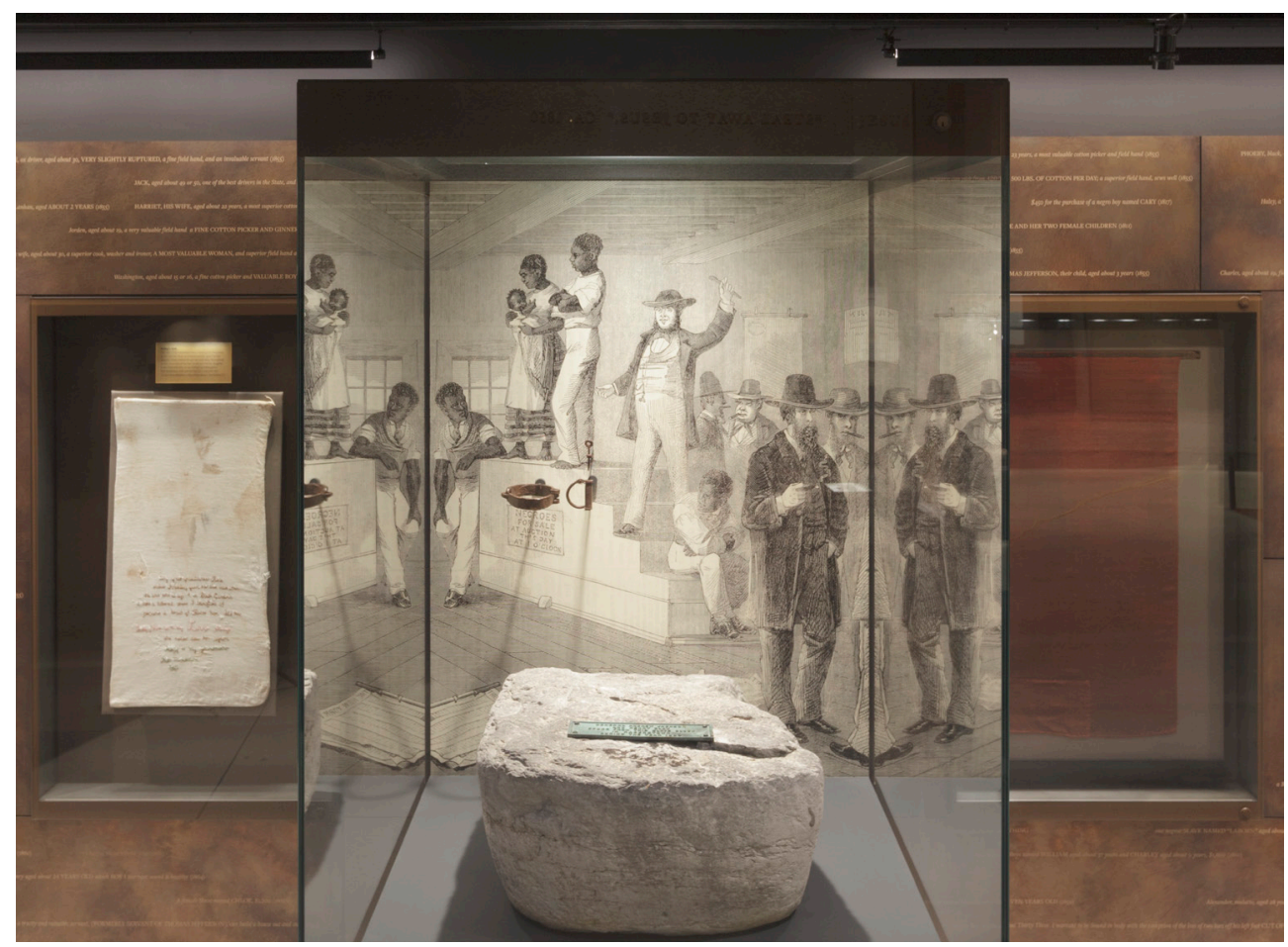

Figure 12: The 'Domestic Slave Trade' section combines a number of design elements associated with poignant stories and difficult histories. This image shows an auction block used in slave sales, displayed before an engraving of an auction. 'Ashley's Sack' is in the case on the left behind the block. Note the massing of excerpts from slave sales arrayed across the wall. Photograph by Alex Jamison/NMAAHC.

barbarous beating, disfigurement, murder and lack of timely justice, the Emmett Till section shows the depths of dehumanising treatment. At the same time, it highlights the resistant humanising gestures of his funeral and the outpouring of support, sympathy, and outrage that followed.

In these two parts of NMAAHC's History Galleries I was deeply moved and tearful. Their design sets up and energises understanding through emotional and empathic connection. Curators and designers work together to depict and represent such narrative and emotional contours, but their impact is not automatic or entirely predictable. Design can heighten potential connections, but ultimately their apprehension depends on the histories, values, and experience that visitors bring to exhibits, though not necessarily in fully explicit ways. Similarly, it is the rare visitor who pays close attention to every detail of exhibit design. Rather, its effects occur in a state of distraction'. Museum design is seldom foregrounded, rarely a focus of direct attention, and usually absorbed 'in incidental fashion. ${ }^{44}$ As Edward Ball notes, 'Exhibition

44 Kratz. 'Rhetorics of Value', 30. See also, W. Benjamin, 'The Work of Art in the Age of Mechanical Reproduction' in H. Arendt (ed.), Illuminations 1936 (New York: Schocken Books, 1968), 217-252; J. Crary, Suspensions of Perception: Attention, Spectacle, and Modern Culture (Cambridge, MA: MIT Press, 1999); R. Rutsky, 'Pop-up Theory: Distraction and Consumption in the Age of Meta-Information', Journal of Visual Culture 1, 3, 2002, 279-294. 
designers are the unacknowledged poets of public history. It is a three-dimensional art, and in a way subconscious in its effects. ${ }^{35}$

Since different visitors respond, understand, and connect with exhibits in varied ways, effective exhibit design should incorporate both interpretive guidance and a certain openness, which together can foster places of potential connection. What is striking about NMAAHC's History Galleries is how often those connections evoke strong emotional responses that are layered with a moral sense. While visitors' particular places and modes of connection were not entirely predictable, it nonetheless made sense to ask people, 'Where did you cry?' because nearly every visitor I spoke with was touched or overcome at some point. While some mentioned exhibit sections, like the two described above, where design and narrative were powerful enough to open that possibility, others mentioned aspects of the exhibit that held personal significance and associations. The latter described how their own lives, memories, and/ or involvements related to people, events, and issues presented. ${ }^{46}$ These were conjoined for some visitors, including an older African American woman whose family lived near the Mississippi town where Emmett Till was murdered. In each instance, the exhibit proffered bridges from specific cases and details to general historical processes and (perhaps) universal experiences. ${ }^{47}$

Such moments of connection might also help the History Galleries to buttress and confirm their broader goal of recasting popular history. Such recasting necessarily involves an implicit and explicit critique of narrative omissions or distortions, portrayals of people and events, and categories previously taken for granted. Scholars of language and politics stress that implicit critique is often most effective in conceptual reframing, which is wrapped up with emotion and values, not simply a matter of rationality, evidence, or logic. ${ }^{48}$ 'The mind thrives on metaphor, narrative, and emotion. ${ }^{49}$

While my analysis here has been limited to the History Galleries, it is worth noting some of the larger designed contours of affect at the NMAAHC, which are

45 E. Ball, 'At last, a Black History Museum', New York Review of Books, 24 November 2016, http://www.nybooks.com/ articles/2016/11/24/smithsonian-black-history-museum/ (accessed 21 January 2018). This would not surprise cognitive linguist George Lakoff, though he does not write on exhibits or design but about language and politics. Lakoff argues that 'an estimated 98 percent of thought is unconscious' and emphasises the role of frames and core conceptual metaphors in shaping how we think through an 'embodied mind'; see G. Lakoff and M. Johnson, Philosophy in the Flesh (New York: Basic Books, 1999). For Lakoff, 'conscious thought is the tip of the iceberg'; G, Lakoff, 'Understanding Trump', 2016. https://georgelakoff.com/2016/07/23/ understanding-trump-2/ (accessed 21 January 2018.) Freedberg's exploration of the compelling emotional power of images and viewers' range of responses is also pertinent; see D. Freedburg, The Power of Images (Chicago: University of Chicago Press, 1989).

46 One conversation also demonstrated visitors' uneven attention and awareness of certain aspects of exhibit design: a first-time visitor noted that he had been struck by the wall with massed excerpts from slaves' bills of sale, but as we then talked about other massing techniques spread through the Galleries, he realised he had not noticed them consciously.

47 In her opening review of the museum, Davis offers another combination of moving moments evoked by both design and personal experience, confiding that she too wept when she saw Ashley's sack in 'The Domestic Slavery' section, and that she 'cried again when I saw Michelle Obama's inauguration dress'; A. Davis, 'After a Century, The New Black History Museum is Finally Here', Refinery, 29, 2016, https://www.refinery29.com/2016/09/123887/smithsonian-nmaahc-museum-exhibits-reviewfirst-visit (accessed 20 May 2018).

48 M. Karlin, 'George Lakoff: In Politics, Progressives Need to Frame Their Values', Truthout, 23 November 2014, http://www.truthout.org/progressive-picks/item/27576-george-lakoff-progressives-cannot-succeed-without-expressing-respect-values (accessed 22 January 2018).

49 S. Rathje, 'The power of framing: It's not what you say, it's how you say it', The Guardian, 20 July 2017, https://www.theguardian. $\mathrm{com} / \mathrm{science} / \mathrm{head}$-quarters/2017/jul/20/the-power-of-framing-its-not-what-you-say-its-how-you-say-it (accessed 22 January 2018). Rathje does psychological research at the Stanford Mind and Body Lab as a student working with Alia Crum, who focuses on 'how changes in subjective mindsets - the lenses through which information is perceived, organized, and interpreted - can alter objective reality through behavioural, psychological, and physiological mechanisms'; see https://mbl.stanford.edu/people (accessed 22 January 2018). 


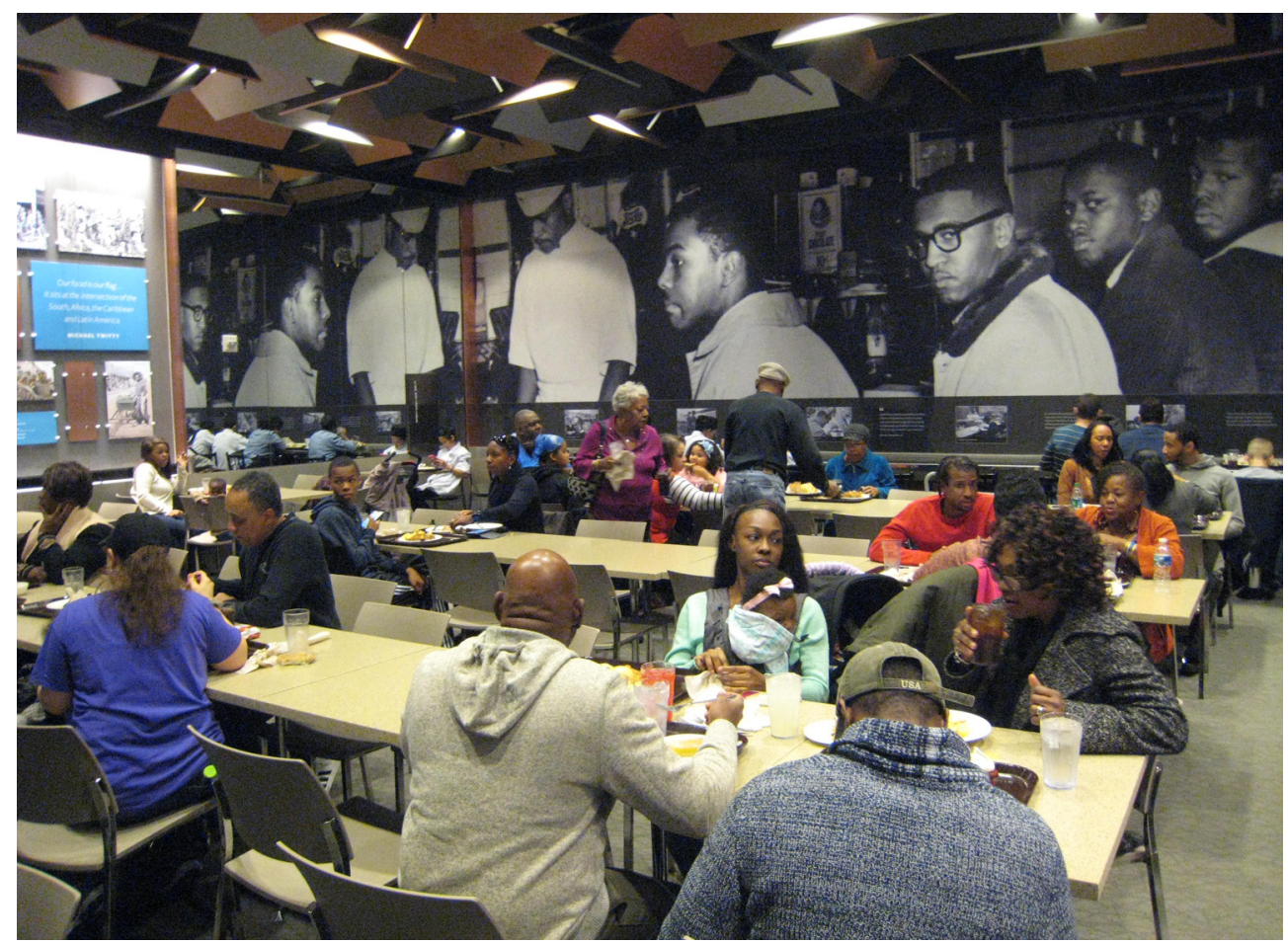

Figure 13: Featuring regional cuisines, NMAAHC's café includes displays on African American food traditions, and a large mural of the 1960 sit-in at the whites-only lunch counter in Woolworth's department store in Greensboro, North Carolina. Photograph by Corinne A. Kratz.

also part of that recasting and within which the History Galleries' powerful connections are situated. On exiting the History Galleries, visitors can immediately enter a Contemplative Court with benches, a calming water feature, and inspirational quotes. Recognising the Galleries' potential emotional impact, and the demands of working through their extensive, dense subterranean displays, ${ }^{50}$ the Court was designed to facilitate reflection, recovery, and rest. A reviewer at the museum's opening noted that 'people came primed for emotionally wrenching presentations', and spoke with a family 'brought to tears' at the end, in the Court. ${ }^{51}$

In contrast to the History Galleries, where visitors climb up to the ground floor through three ramped levels, the museum's Community Galleries and Culture Galleries are located on the upper levels. These offer largely celebratory stories of African American contributions to sports, the military, business, entertainment, the arts, music, and much more. The emotional contrast is striking, offering 'a feeling

50 The NMAAHC has an average visitor dwell time of six hours, more than three times as long as most museums; see https:// nmaahc.si.edu/about/news/national-museum-african-american-history-and-culture-reaches-milestone-1-million-visitors (accessed 20 May 2018).

51 M. Ryzik, 'Pride and Pain on Opening Day at a Museum of African American History', New York Times, 27 September, 2016, C2, https://www.nytimes.com/2016/09/27/arts/design/pride-and-pain-on-opening-day-at-a-museum-of-african-american-history. html (accessed 20 May 2018); see also McGlone, 'African American Museum'. 
of relief. ${ }^{52}$ In addition to these broad topographies of affect planned into the NMAAHC's spatial layout and exhibits, the museum's Sweet Home Café is often marked by friendly camaraderie among patrons. Sitting beneath a photographic mural of the 1960 Greensboro, North Carolina lunch-counter sit-in and displays about African-American regional foodways (Figure 13), I swapped reactions to the exhibits and recipes for greens with other visitors. Like the tearful moments and strong emotions evoked in the History Galleries, the museum's more varied and complex topography of affect may also hold diverse meanings and associations for visitors, but design lays their groundwork.

This design analysis may provide ways to help think about forced disappearance, the missing and missed, and their broader situations, which have become the focus of exhibitions, display, and performance. Outside formal exhibit settings, too, these topics have long been caught up in the politics of knowledge, language, and representation. How are similar design techniques and approaches put to work elsewhere? How have massing techniques been incorporated for particular ends and emphases? Do designed moments of potential connection and critique help convey what it means to be held in the web of the missing and missed, and how those webs are woven? How do they join specific cases and experiences to historical patterns and processes in other settings and to seeming universals?

The dynamics of personhood, humanisation and dehumanisation are central to this and certainly common to the NMAAHC History Galleries, campaigns around the missing, and other sites of thanatourism and dark tourism alike. ${ }^{53}$ The use of names and various modes of naming have been powerful resources for addressing such dynamics. Yet exhibits also use personal objects and images to foreground tensions of personhood, sometimes massing them to also place individuals within systemic processes. 'What does it mean to name and rehumanise the dead?', ask Forensic History Group in framing the workshop that led to this special issue. ${ }^{54}$ How are exhibits part of such processes and rituals of rehumanisation more broadly? What do they offer?

Notions of the forensic might offer one way to think about this and to conclude this paper. Forensic examinations and forensic histories might well be part of the research and analysis undergirding the histories and cases eventually presented in

52 V. Cunningham, 'Making a Home for Black History', The New Yorker, 29 August 2016. https://www.newyorker.com/ magazine/2016/08/29/analyzing-the-national-museum-of-african-american-history-and-culture (accessed 20 May 2018).

53 R. Hartmann, 'Dark Tourism, Thanatourism, and Dissonance in Heritage Tourism Management', Journal of Heritage Tourism 9, 2, 2014, 66-182; D. Light, 'Progress in Dark Tourism and Thanatourism Research', Tourism Management 61, 2017, $275-301$. The Assin Manso Garden of Remembrance in Ghana, a slave heritage site, addresses the dilemma posed by memorialising and rehumanising the massive numbers of people who were taken and perished during the slave trade by creating representatives of return and a list of names. An area labelled Ancestral Graveyard features two tiled graves which hold the remains of 'Samuel Carson and Mother Crystal, whose skeletal remains were returned from the United States of America and Jamaica in 1998 for re-interment to Ghana signifying the return to the home land', https://samuelmensah.wordpress.com/2013/03/20/our-touristattractions-the-case-of-assin-the-un-explored-potential/ (accessed 23 January 2018). Visitors can symbolically join this act of return by making a donation to have their names inscribed on the Memorial Wall of Return.

Forensic History Group, 'Missing and Missed', 4. 
the NMAAHC and other exhibits. ${ }^{55}$ Might exhibit design be seen as part of a philosophical forensics, one that offers ways to examine the assumptions that ground understandings of missingness in other material and experiential ways? How are different modes of missing addressed, displayed, alluded to, narrated, represented? What categories do they seem to constitute or reshape? What is and isn't addressed? In thinking about how to present and grapple with missingness through designed space, exhibit design introduces another avenue for re-examining the ways that we know, the stories we tell, the engagements we experience, and for 'explor[ing] missingness as a condition that is epistemological, ontological, historical, political, legal and aesthetic, and which evades recovery, inclusion and representation. ${ }^{56}$

55 Forensic testing has been part of some lynching investigations, for instance, including exhuming Mary Phagan's remains in relation to the 1915 Leo Frank lynching outside Atlanta. The National Memorial for Peace and Justice and associated Legacy Museum, opened in 2018 in Montgomery, Alabama, document the thousands of lynchings in the US (https://eji.org/legacymuseum, accessed 21 May 2018). Their designs, according to one reviewer, 'combine the kind of forensic clarity typical of the civil rights lawyers behind the effort and the expressiveness of artists whose work is brought powerfully to bear throughout.' M. Schumacher, 'Alabama Memorial Captures the Scale of Racial Terror in the US', Milwaukee Journal Sentinal, 3 May 2018, https:// www.jsonline.com/story/entertainment/2018/05/03/alabama-memorial-captures-scale-racial-terror-u-s/551648002/ (accessed 21 May 2018).

56 Forensic History Group, 'Missing and Missed', 1. 